\title{
Epidemiological Aspects of Oxacillin-Resistant Staphylococcus spp.: The Use of Molecular Tools with Emphasis on MLST
}

\author{
André Martins and Maria de Lourdes Ribeiro de Souza da Cunha \\ UNESP- Univ. Estadual Paulista, Biosciences Institute, Botucatu, SP \\ Brazil
}

\section{Introduction}

Studying infections caused by the Staphylococcus spp. genus is highly important for human health given that such organisms are causal agents of superficial infections, such as abscesses and impetigo, as well as of systemic infections, namely bacteremia and osteomyelitis. This genus is divided into two large groups. The first group is characterized by the production of enzyme coagulase, and its main representative is $S$. aureus, which is frequently associated with a large variety of infections. The second group, known as coagulase-negative staphylococci (CoNS), is usually associated with immunocompromised patients or those who use catheters. (Kloos \& Bannerman, 1995). The main CoNS species associated with infection in humans are $S$. epidermidis, S. haemolyticus, S. saprophyticus, $S$. cohnii, S. xylosus, S. capitis, S. warneri, S. hominis, S. simulans, S. saccharolyticus, S. auricularis, S. caprae, S. lugdunensis and S. schleiferi (Kloos \& Bannerman, 1995).

Several studies have reported increased prevalence of CoNS infection in hospitals, which is usually associated with resistance to the antibiotic of choice for treatment. Hence, this is a serious clinical and epidemiological problem (Jain et. al., 2008).

The use of methicillin and other semi-synthetic penicillins, such as oxacillin and penicillinase-resistant methicillin, which began in 1959, represented a significant phase in anti-staphylococcal therapy. The first report on methicillin resistance was in 1961, a short time after its use was implemented (Hiramatsu et al, 2001). In Brazil, it is estimated that the frequency of oxacillin resistance is high among $S$. aureus samples, particularly in large and in university hospitals. Gales (2009) described an oxacillin resistance rate of $31 \%$ in a multicenter study involving four Brazilian hospitals. As regards CoNS, 78.7\% of the samples were resistant. At the Botucatu School of Medicine University Hospital - SP, approximately 45\% of the $S$. aureus samples from hemocultures were positive for the mecA gene (Martins et al., 2010). In a study conducted at the neonatal intensive care unit of the same hospital, a total of $18 \%$ of MRSA samples was found (Pereira et al., 2009). According to a study by Sader et al. (2004) in Latin America and Brazil, respectively, $80.4 \%$ and $84.6 \%$ of the CoNS samples from hemocultures were oxacillin resistant.

Oxacillin resistance in CoNS samples varies significantly among the different species in the genus, a fact that reinforces the importance of their correct identification (Secchi et al., 2008). 
Although S. epidermidis is the most frequently found species (Vuong \& Otto, 2002), others are also associated with human infection, such as $S$. haemolyticus, which can be multiresistant and present intermediate resistance to vancomycin (Secchi et al., 2008). The main resistance mechanism is the presence of the mecA gene, inserted in the chromosomal cassette, known as staphylococcal chromosomal cassette mec (SCCmec). The detection of this gene and the typing of the chromosomal cassette by means of various molecular methods are important tools for the diagnosis and epidemiology of oxacillin-resistant Staphylococcus spp.

There are eleven SCCmec types, with subtypes, which are characterized by molecular tools, such as Multilocus Sequence Typing (MLST), pulsed-field gel electrophoresis (PFGE), spa typing and Multiplex PCR for SCCmec detection. They are useful in the characterization and detection of alterations in molecular structure. By using these methods, it was possible to identify pandemic clones as well as to characterize strains causing outbreaks in hospitals. Among these methods, the MLST is noteworthy due to its high reproducibility and capacity of detecting pandemic clones. Given the fact that vancomycin is a therapeutic option for oxacillin-resistant samples, with the emergence of vancomycin-resistant Staphylococcus spp., the characterization of circulating strains and clones is highly important. This chapter aimed at addressing aspects related to the molecular epidemiology in Staphylococcus spp. since these microorganisms have been increasingly frequent as agents of nosocomial and community infection.

\section{Epidemiological aspects}

Oxacillin resistance in CoNS is a problem in hospitals around the world, and there are reports of oxacillin-resistant samples in all continents (Witte, 1999). The use of methicillin, a semisynthetic penicillin, commenced in 1959, and only two years after its first use, the first report of a methicillin-resistant Staphylococcus spp. sample was published (Hiramatsu et al., 2001).

Oxacillin resistance rates vary among various studies, but they are usually high, above 50\%. Chaudhury \& Kumar (2007) reported that, in a study conducted in a tertiary Indian hospital, $64.6 \%$ of the CoNS samples were oxacillin resistant. The most prevalent species was $S$. haemolyticus, isolated from urine samples. Another study also performed in India, described resistance levels of approximately $63 \%$ (Jain et al., 2008).

In the European continent, several reports described high oxacillin resistance levels in hospital wards. In a study analyzing samples collected from various hospitals in Eastern Europe in 2005, Sader et al. (2007) reported oxacillin resistance levels in CoNS which varied from $54.8 \%$ in Sweden to $83.3 \%$ in Greece. A study conducted at a university hospital in Turkey found $54.4 \%$ of resistant samples from a total of 158 isolated samples (Ercis et al., 2008). The rates found by a multi-center study conducted in the USA in 2007 and 2008 were of $74 \%$ of CoNS oxacillin-resistant samples (Sader \& Jones, 2009).

Nevertheless, in the last few years, resistance levels have stabilized. In Spain, a multi-center study on 146 hospitals detected oxacillin resistance in $61.3 \%$ of the samples in 2002 and $66.7 \%$ in 2006 (Cuevas et al., 2008). In Brazil, recent studies showed resistance rates of $69 \%$ (Caierão et al., 2004), 78.4\% (Perez \& d'Azevedo 2007) and even 88.1\% (Antunes et al., 2007). In the case of non-epidermidis CNS, Secchi et al. (2008) reported $71 \%$ of resistant samples. 
Based on the described reports, it is clear that oxacillin resistance is prevalent in hospital in all continents, a fact that reinforces the importance of good antibiotic therapy practices and of infection control measures in hospitals.

\section{Oxacillin resistance}

Oxacillin resistance is associated with the drug's reduced capacity to adhere to the penicillin-binding protein (PBP), thus also losing its capacity to lyse the bacterial cell. There are three mechanisms of resistance to semi-synthetic penicillinases, a group of drugs in which oxacillin is included. The first is related to the hyperproduction of $\beta$-lactamases, enzymes that cleave the drug's $\beta$-lactam ring, thus inactivating it (McDougal \& Thornsberry, 1986). The second mechanism, known as MOD-SA, occurs when normal PBPs have reduced affinity with oxacillin (Tomasz et al., 1989). The third and most important mechanism is the presence of the mecA gene. This gene codifies a changed PBP, known as PBP 2a, thus preventing its binding to oxacillin (Zhang et al., 2009).

Although resistance mediated by the mecA gene is present in all cells of the population with intrinsic resistance, it can only be expressed by a small percentage of such cells, thus leading to the so-called heterogeneous resistance. Resistance expression in lineages with intrinsic resistance has been categorized into four phenotypic classes; classes 1 to 4 , in which class 1 is the most heterogeneous and class 4 is the homogeneous one (Tomacz et al., 1991). The majority of cells (99.9 or $99.99 \%)$ in the culture of lineages with class-1 heterogeneous resistance show minimum inhibitory concentration (MIC) of 1.5 to $3 \mu \mathrm{g} / \mathrm{ml}$, but such culture also contains a small number of bacteria $\left(10^{-7}\right.$ to $\left.10^{-8}\right)$ that could form colonies even in the presence of $25 \mu \mathrm{g} / \mathrm{ml}$ or more of oxacillin. In class-2 lineage cultures, the majority of cells ( $\geq$ $99.9 \%$ ) show MIC of 6 to $12 \mu \mathrm{g} / \mathrm{ml}$, and in these cultures, the frequency of highly resistant cells (capable of growing in the presence of $25 \mu \mathrm{g} / \mathrm{ml}$ ) is higher $\left(10^{-5}\right)$ than in class- 1 lineages (Tomacz et al. , 1991). Class-3 lineage cultures consist of bacteria (99 to 99,9\%) that show high levels of oxacillin resistance (MIC $=50$ to $200 \mu \mathrm{g} / \mathrm{ml}$ ), but they usually have a subpopulation $\left(10^{-3}\right)$ of highly resistant cells that are capable of forming colonies even in the presence of 300 to $400 \mu \mathrm{g}$ de oxacillin/ $\mathrm{ml}$. Class- 4 cultures comprise cells with homogeneous resistance, with all cells showing high resistance levels and MIC of 400 to 1,000 $\mu \mathrm{g} / \mathrm{ml}$ (Tomacz et al., 1991).

The phenotypic expression codified by the mecA gene is affected by various factors, including $\mathrm{pH}$, temperature and osmolarity (Swenson, 2002). When proper conditions are used for laboratory MRSA detection, including Mueller-Hinton agar supplementation with $\mathrm{NaCl}$ and adequate temperature and time, as recommended by CLSI (Clinical and Laboratory Standards Institute), detection is achieved without much difficulty. However, for more heterogeneous lineages, detection can be more difficult, even with reference methods (Swenson, 2002).

Adequate detection of oxacillin resistance mediated by the mecA gene is important for clinical laboratories. Although the recommended methods detect most of the oxacillinresistant lineages, there are two situations that require additional phases to confirm sensitivity or resistance. The first is the occurrence of extremely heterogeneous lineages that are found to be sensitive by reference methods. The second is the occurrence of borderline resistance (MIC close to the sensitivity breakpoint), which must be differentiated from 
resistance mediated by the $m e c A$ gene as long as the clinical significance of the resistance determined by the mecA gene is greater.

The mecA gene is inserted in a transposable genetic element known as Staphylococcal Chromosomal Cassette mec (SCCmec). This element varies in its constitution and is divided into eleven types. The typing of SCCmec types is useful as an epidemiological tool (Mombach Pinheiro Machado et al., 2007) given that the different types are more prevalent in hospital and community environments. The SCCmec types (IWG-SCC, 2009) differ from one another in relation to the number of genes that they carry in their gene architecture (Hiramatsu et al., 2001). Some of these types are carriers of resistance genes that are determinant for multiple antibacterial drugs. In addition to beta-lactam antibiotics, macrolides, lincosamides, streptogramins, aminoglycosides and tetracycline are noteworthy. Hence, when a bacterial cell acquires such SCCmec, it at once acquires a multiple-resistance phenotype (Ito et al., 2003).

The SCCmec types have been defined by the combination of two parts: the ccr complex and the mec complex, with three phylogenetically distinct $c c r$ genes classified as: $c c r A, c c r B$ and ccrC. Additionally, there are five classes of mec gene complexes (classes $A, B, C 1, C 2$ and class D) (Ito et al., 2004; IWG-SCC, 2009). The different SCCmec types are classified as: type-I SCCmec (class B and ccrA1B1 mec gene complex), type-II SCCmec (class A and ccrA2B2 mec gene complex), type-III SCCmec (class $A$ and ccrA3B3 mec gene complex), type-IV SCCmec (class $B$ and ccrA2B2 mec gene complex), type-V SCCmec (class $C 2$ and $c c r C$ mec gene complex), type-VI SCCmec (class $B$ and ccrA4B4 mec gene complex), type-VII SCCmec (class $C 1$ and $c c r C$ mec gene complex) and type-VIII SCCmec (class A and ccrA4B4 mec gene complex). The remaining region of SCCmec is called the J region (Joining region), which constitutes non-essential components of the cassette that can carry additional antimicrobial resistance determinants (Hanssen \& Sollid, 2006; IWG-SCC, 2009). Recently, types IX (class $\mathrm{C} 2$, ccr1 mec gene complex), $\mathrm{X}$ (class $\mathrm{C} 1$, ccr7 mec gene complex) and XI (class E, ccr8 mec gene complex) have been described (IWG-SCC, 2011) (Table 1).

\begin{tabular}{ccc}
\hline SCCmec type & mec gene complex & $c c r$ gene complex \\
\hline I & B & $1(\mathrm{~A} 1 \mathrm{~B} 1)$ \\
II & $\mathrm{A}$ & $2(\mathrm{~A} 2 \mathrm{~B} 2)$ \\
III & $\mathrm{A}$ & $3(\mathrm{~A} 3 \mathrm{~B} 3)$ \\
IV & $\mathrm{B}$ & $2(\mathrm{~A} 2 \mathrm{~B} 2)$ \\
V & $\mathrm{C} 2$ & $5(\mathrm{C} 1)$ \\
VI & $\mathrm{B}$ & $4(\mathrm{~A} 4 \mathrm{~B} 4)$ \\
VII & $\mathrm{C} 1$ & $5(\mathrm{C} 1)$ \\
VIII & $\mathrm{A}$ & $4(\mathrm{~A} 4 \mathrm{~B} 4)$ \\
IX & $\mathrm{C} 2$ & $1(\mathrm{~A} 1 \mathrm{~B} 1)$ \\
X & $\mathrm{C} 1$ & $7(\mathrm{~A} 1 \mathrm{~B} 6)$ \\
XI & $\mathrm{E}$ & $8(\mathrm{~A} 1 \mathrm{~B} 3)$ \\
\hline
\end{tabular}

Source: http://www.sccmec.org/Pages/SCC_TypesEN.html. Accessed on 06/20/2011

Table 1. SCCmec types identified in S.aureus

The first three types were detailed by Ito et al. in 2001, and the same author also reported and described type V in 2004. Ma et al. (2002) described type IV, which is mainly found in 
community samples. Types I, II and III are mainly responsible for nosocomial infections, and they are significantly larger than the last types IV and V. Type-I cassette was described with a size of $34.364 \mathrm{bp}$, and it is the largest of the three. This cassette does not feature any inserted transposons or plasmids that provide resistance to other drugs besides methicillin or to heavy metals. It has a sub-type known as IA, which differs from type I for having an integrated plasmid, pUB110 (Shore et al., 2005).

The second cassette, referred to as II, has $53.017 \mathrm{bp}$, and in addition to the mecA and mecRI genes, which cause methicillin resistance, it contains transposon Tn 554. The latter is responsible for the resistance of this sample type to erythromycin and streptomycin. This cassette has a sub-type that is referred to as IIA, with a size of $40 \mathrm{~Kb}$, thus being a little smaller than type II (Shore et al., 2005).

Type-III cassette, the largest of the five types, has a size of $66.896 \mathrm{bp}$ and contains genes mecA, mecRI, transposons Tn 554 and $\psi$ Tn 554 and plasmid pt 181. Transposon $\psi$ Tn 554 induces cadmium resistance, and plasmid pt 181 is responsible for tetracycline and mercury resistance. In addition to the information described above, the authors also mentioned differences between the ccr gene types, by describing, in type-III SCCmec, a gene that is not present in the other types and is referred to as $\psi \mathrm{ccr}$. They also suggested that some of the resistance characteristics in type III can be used as selective markers. This cassette type presents two sub-types: IIIA, which does not have plasmid pt 181 and flanks with element IS 431, and IIIB, where there are no copies of plasmids pt 181 or tn 554 (Shore et al., 2005).

Type-IV SCCmec is mainly responsible for community infections. It is a small element that does not carry other resistance genes, except for mecA. It is also divided into multiple subtypes, which suggests that type-IV SCCmec is highly transmittable (Ito et al., 2004). The four sub-types of type-IV, -IVA, -IVB, -IVC and -IVD cassettes differ for presenting different sequences on the left extremity of the ccr complex, which is known as L - C Region (Shore et al., 2005).

Type-V SCCmec was identified by Ito et al. (2004) in an Australian isolate. It has the size of $27.624 \mathrm{bp}$, and it is a little larger than SCCmec IV although smaller than the other existing types. Similarly to type IV, it has only genes that codify methicillin resistance; however, differently from the other elements in this family, type $\mathrm{V}$ has a new $c c r$ gene type that is characterized as type $\mathrm{c}$ and is individually found, contrarily to other elements, which have a pair of such genes. Another new element found only in type $\mathrm{V}$ is a restriction and modification system codified by genes V22 and V23. Recent studies associate the presence of this mec cassette type with community infections (O'Brien et al., 2005; Ho et al., 2007).

Oliveira et al. (2006) characterized type-VI SCCmec, which is found in samples belonging to the pediatric clone of MRSA (Methicillin Resistant S.aureus) samples and previously typed as SCCmec IV. The authors described differences in the ccrAB complex, identified as type 4, and the presence of the type-B mec complex, which does not have the mecl gene.

Type-VII SCCmec was identified by Higuchi et al. (2008) through a detailed analysis of community S.aureus samples isolated in Taiwan. It has a size of $41.347 \mathrm{bp}$, and its mec complex is homologous to that found in type $\mathrm{V}$, but presents substitutions, insertions and rearrangements that differentiate it. The main characteristics of this cassette type are the presence of the $c c r C$ complex, of transposon UIS431 and of a unique sequence on the right side of the cassette which is referred to as orf35. 
Recently, Zhang et al. (2009) have described a new SCCmec type which has been denominated as SCCmec VIII and was found in an MRSA sample from a hospital. This new cassette has a size of 32.168 base pairs, and genes mecA mecR 1 mecl of the mec complex and ccrA4 ccrB4 of the ccr complex are present in addition to transposon Tn554, which is also present in type II.

\section{Molecular epidemiology}

In addition to the characterization of SCCmec types as an epidemiological tool, other methods are available for molecular epidemiology studies, such as Pulsed Field Gel Electrophoresis (PFGE), Multilocus Sequence Typing (MLST) and spa typing, which allow for the identification of circulating bacterial clones in hospitals and in the community.

PFGE is a method that uses restriction enzymes to cleave the extracted DNA, and in the case of the Staphylococcus genus, the enzyme used is SmaI. The fragments are separated in agarose gel. The direction of the electrical field is periodically changed, forming a $120^{\circ}$ angle. This allows for fragments of up to $12 \mathrm{mb}$ to be separated, contrarily to conventional electrophoresis, which is not capable of separating fragments that are larger than $50 \mathrm{~kb}$ (Herschleb et al., 2007). This method is generally used in local studies, such as in hospital outbreaks, which allows for identifying the circulating type.

The sequencing of constitutive bacterial genes can also be used as an important epidemiological tool. The method known as spa typing investigates polymorphisms on a single locus. It can discriminate between PFGE and MLST and is also applied in local studies and for detecting pandemic clones (Malachowa et al., 2005).

Another methodology that uses the sequencing and analysis of genetic polymorphisms is MLST. It analyzes the sequence of seven constitutive genes (gmk, pta, dfp, gtr, mutS, pyrR, and $x p t$ ) and compares them with the sequences of each allele in the locus, which are previously numbered. The combination of the alleles identified in each gene determines the profile of the sample. (Aanensen \& Spratt, 2005). It is the most adequate methodology for detecting pandemic clones given that the investigated genes are constitutive, with low mutation rates when compared to the analysis of the whole chromosome, in the case of PFGE (Miragaia et al., 2007).

\section{Pandemic clones of MRSA samples}

Currently, Staphylococcus spp. samples have been typed in numerous epidemiological studies by means of the methods described above. By using these tools, 05 large pandemic clones have been described. These are the Brazilian clone, characterized by SCCmec IIIA, MLST 2-31-4-4-3 (ST 239); the Iberian clone with type-IA SCCmec, and MLST 3-3-1-1/12-4-4-16 (ST 247); the clone known as New York / Japan, with type-III SCCmec, pattern MLST 1-4-1-4-121-10 (ST 05); the Hungarian clone, with SCCmec III, MLST 2-3-1-1-4-4-3 (ST 239); the pediatric clone, with type-IV SCCmec, MLST 1-4-1-4-12-1-10 (ST 05) and the last large clone known as EMRSA-16, SCCmec II MLST 15-12-16-02-16-02-25-17-24-24-24 (ST 36) (Oliveira et al., 2002; Melter et al., 2003; Velásquez-Meza et al. 2004; Aires de Souza \& De Lencastre, 2004, Aires Ribeiro et al., 2005).

In our scenario, the predominant MRSA samples belong to the Brazilian clone (Oliveira et al., 2001). The first report on the emergence of this clone dates to 1992-93 in various hospitals 
in Brazil. The samples were characterized as belonging to the same clone by methods such as PFGE and by showing patterns of transposon Tn554 and the polymorphism of the mecA gene (Teixeira et al., 1995). In other countries, the Brazilian clone is also disseminated, as is the case of the Czech Republic, where the isolation of this clone represented $80 \%$ of the MRSA samples found in 1996-1997 (Melter et al., 2003). The Brazilian clone was also described in India, in two hospitals in the region of Bengalore, conjointly with the Hungarian clone (SCCmec III) (Arakere et al., 2005)

Other clones are distributed in several parts of the world. The Iberian clone was firstly described in samples from hospitals in Barcelona and Madrid, Spain, and in Lisbon, Portugal. These samples were typed by the PFGE method and probe hybridization, producing a pattern that characterized them as belonging to the same clone. This clone is also described in other countries, such as the Czech Republic (Melter et al., 2003). The clone known as New York - Japan, firstly isolated in the USA in 1994-98 and in Japan in 1997-98 (Oliveira et al., 2002), was also predominant in Mexico during a study on 98 MRSA samples, thus replacing the local clone, known as Mexican (PFGE M, type-IV SCCmec), in nosocomial infections (Velasquez-Meza et al., 2004).

The Hungarian clone, firstly identified in Hungary in 1993-94, was characterized by the same methods used for the clones described above in studies on MRSA samples from hospitals in 06 provinces in that country (De Lencastre, 1997). The pediatric clone was isolated in large numbers in 1996-98 in Colombia, and it is also found in Argentina and Poland in 1994-98 and 1990-98 (Oliveira et al., 2002).

The last of the large pandemic clones, referred to as EMRSA-16, is prevalent in hospitals in the United Kingdom, Mexico and Greece, in addition to being responsible for an outbreak in Sweden from 1997 to 2000 (Aires de Souza \& De Lencastre, 2004).

\section{Epidemiology and MLST}

The MLST method was developed by Maiden et al. (1998) by the sequencing and analysis of the loci of eleven constitutive genes of Neisseria meningitidis, and it is presently applied in molecular epidemiology studies on various pathogens, among which are $S$. aureus and $S$. epidermidis.

This methodology has been used in numerous studies on molecular epidemiology with good results due its good reproducibility, thus allowing for the detection of pandemic clones from circulating $S$. aureus and S. epidermidis samples.

Geng et al. (2010) reported the presence of clone ST59-MRSA-IV in China in community samples isolated from 47 children with impetigo and abscesses. In Malaysia, a study on 36 samples isolated from a hospital in Klang Valley for a five-month period reported a rate of $83.3 \%$ of samples belonging to clone ST 239 SCCmec III (Neela et al., 2010).

MLST has been used for studies in which circulating clones are identified in replacement of another already established clone. Sola et al. (2006) reported the emergence of a new clone identified as ST5 in hospitals in Cordoba, Argentina, in replacement of the Brazilian clone (ST239), which circulates in that region. In that study, 103 MRSA samples isolated from April to June 2001 and 31 MSSA samples isolated from 1999 to 2002 were used. 
Previous studies have used MLST for comparison between samples and the prevalence between different pandemic clones. Campanille et al. (2009) analyzed 301 MRSA samples isolated from 19 Italian hospitals from 1990 to 2001. An increase of clone ST228, known as Italian clone, was observed from 2000 to 2007, conjointly with the decrease of clone ST247 (Iberian clone) when compared to the 1990-1999 period.

Clone ST228 is also associated with patients with cystic fibrosis. A study conducted on 93 MRSA samples isolated from patients with that disease at a treatment center in Madrid, Spain, identified 15 different PFGE patterns. A sample of each of these patterns was typed by MLST, with clone ST228 showing higher prevalence, with eight pulsetypes, followed by ST5, with two pulsetypes, and ST247, ST72 and ST255 with one pulsetype each (Molina et al., 2008).

In addition to epidemiological studies in hospitals and the detection of these pandemic clones from MRSA samples, the MLST method has been used to detect the transmission of oxacillin-resistant samples from animal reservoirs to humans, including its detection in hospitals. Some studied have detected the presence of MRSA clones in swines, thus emphasizing the importance of such animals as reservoirs. Smith et al. (2009) reported the presence of ST398 samples in swines and farmers in the mid-western region of the United States, which suggests transmission between animals and their breeders. In Germany, 1,600 swabs from swines from 40 farms were analyzed in a study where samples typed as ST398 were also identified (Köck et al., 2009).

MLST is usually used for detecting pandemic clones with good results. But this method can also be utilized for characterizing samples involved in hospital outbreaks.

Peacock et al. (2002) compared the MLST and PFGE methods in a study conducted on 104 S. aureus samples isolated from nasal swabs from patients under renal therapy. The isolated samples were typed by the MLST and PFGE methods with a similar discriminatory power between the two techniques for identification of circulating samples in hospitals.

Vindel et al. (2009) analyzed 463 S.aureus samples isolated from 145 Spanish hospitals in 2006. In addition to MLST, several methodologies such as PFGE, spa typing, SCCmec characterization and agr typing were used. MLST showed good correlation with the methodologies used for detecting circulating samples, with applicability in localized nosocomial studies.

The combination of the two molecular epidemiology techniques can increase discriminatory power for analysis of different clones. Cookson et al. (2007) reported that the combination of the MLST and SCCmec methods are more appropriate for multi-center studies. The authors analyzed MRSA samples from various European countries by means of PFGE, MLST, SCCmec analysis and spa typing.

\section{Vancomycin-resistant S. aureus (VRSA)}

Detection of oxacillin resistant staphylococci is important to guide therapies and also to avoid use of vancomycin, which is an antimicrobial agent with therapeutic complications, and can lead to selection of resistant strains. Acquired microbial resistance to vancomycin is a growing problem, in particular, within healthcare facilities such as hospitals. The widespread use of vancomycin makes resistance to the drug a significant worry, especially 
for individual patients if resistant infections are not quickly identified and the patient continues the ineffective treatment. Vancomycin-resistant Enterococcus (VRE) emerged in 1987 and the transfer potential of such resistance to other bacteria, vancomycin resistance surveillance has been an object of great scientific interest worldwide. Vancomycin resistance emerged in more common pathogenic organisms during the 1990s and 2000s, including vancomycin-intermediate Staphylococcus aureus (VISA) and vancomycin-resistant Staphylococcus aureus (VRSA).

In 1996, the first clinical S. aureus isolate with reduced vancomycin sensitivity, with MIC value in the intermediate range (MIC $=8 \mu \mathrm{g} / \mathrm{ml}$ ) and referred to as VISA was reported in Japan (Hiramatsu et al. 1997). Additionally, in June 2002 [44], eight patients with infections caused by $S$. aureus with reduced vancomycin sensitivity were confirmed in the United States. One month later, the Centers for Disease Control and Prevention (CDC) published the first reported on vancomycin-resistant $S$. aureus (VRSA, with MIC $=$ or $\geq 32 \mu \mathrm{g} / \mathrm{ml}$ ) in a patient in Michigan, United States. The sample isolated from the patient contained the van $A$ gene as well as the mecA gene for oxacillin resistance. The presence of the van $A$ gene in this VRSA suggests that resistance may have been acquired through the passage of genetic material from vancomycin-resistant enterococci to $S$. aureus. In October of the same year [44], the second clinical isolate of VRSA was reported in a patient in Pennsylvania. The VRSA isolate also contained the vanA and the mecA genes. The presence of the vanA gene suggests that the resistance determinant was acquired from vancomycin-resistant Enterococcus isolated from the same patient. April 2004, the third VRSA isolated from a patient in New York was reported. The isolate also contained the oxacillin- and vancomycinresistance mecA and vanA genes, respectively. According to CDC, the three VRSA isolated did not seem to be epidemiologically related (CDC 2002; CDC 2004). The CDC (2010) has recently confirmed the 11th case of vancomycin resistant Staphylococcus aureus (VRSA) infection since 2002 in the United States (Table 2). This serves as a reminder about the

\begin{tabular}{|c|c|c|c|c|}
\hline Case & State & Year & Age & Source \\
\hline 1 & Michigan & 2002 & 40 & $\begin{array}{l}\text { Plantar ulcers \& } \\
\text { Catheter tip }\end{array}$ \\
\hline 2 & Pennsylvania & 2002 & 70 & Plantar ulcer \\
\hline 3 & New York & 2004 & 63 & $\begin{array}{l}\text { Urine from a } \\
\text { nephrostomy tube }\end{array}$ \\
\hline 4 & Michigan & 2005 & 78 & Toe wound \\
\hline 5 & Michigan & 2005 & 58 & $\begin{array}{l}\text { Surgical site wound } \\
\text { after panniculectomy }\end{array}$ \\
\hline 6 & Michigan & 2005 & 48 & Plantar ulcer \\
\hline 7 & Michigan & 2006 & 43 & Triceps wound \\
\hline 8 & Michigan & 2007 & 48 & Toe wound \\
\hline 9 & Michigan & 2007 & 54 & $\begin{array}{l}\text { Surgical site wound } \\
\text { after foot amputation }\end{array}$ \\
\hline 10 & Michigan & 2009 & 53 & Plantar foot wound \\
\hline 11 & Delaware & 2010 & 64 & Wound drainage \\
\hline
\end{tabular}

Source: CDC (2010)

Table 2. Vancomycin resistant Staphylococcus aureus (VRSA) infection in the United States 
important role of clinical laboratories in the diagnosis of VRSA cases to ensure prompt recognition, isolation, and management by infection control personnel. Appropriate antimicrobial prescribing by healthcare providers, adherence to recommended infection control guidelines, and, ultimately, the control of both MRSA and VRE are necessary to prevent further emergence of VRSA strains.

\section{Conclusions and perspectives}

Given the high rates of oxacillin resistance reported in various countries and the emergence of vancomycin-resistant MRSA samples, further detailed studies on the characteristics of circulating strains in hospitals and the characterization of clones prevailing in larger regions are necessary since the different MRSA clones vary in virulence and antimicrobial resistance. The molecular epidemiology methods are useful tools in these types of study, and the MLST technique is especially useful due to its versatility, easy performance and high reproducibility, with applications in localized studies, such as in the characterization of outbreaks and in the detection of circulating clones in large regions.

\section{Acknowledgements}

The support by FAPESP is gratefully acknowledged.

\section{References}

Aanensen, D.M.; Spratt, B.G. (2005) The multilocus sequence typing network: mlst.net. Nucleic Acids Research. Vol.33, pp. 728-33. ISSN 1362-4962

Aires de Sousa, M.; De Lencastre, H. (2004) Bridges from hospitals to the laboratory: genetic portraits of methicillin-resistant Staphylococcus aureus clones. FEMS Immunology and Medical Microbiology, Vol 40, pp. 101-111. ISSN: 0928-8244

Arakere, G.; Nadig, S.; Swedberg, G.; Macaden, R.; Amarnath, S.K.; Raghunath, D. (2005) Genotyping of methicillin-resistant Staphylococcus aureus strains from two hospitals in Bangalore, South India. Journal of Clinical Microbiology. Vol. 43, pp.3198-3202. ISSN 1098-660X

Antunes, A.L.S.; Secchi, C.; Reiter, K.C.; Perez, L.R.R.; Freitas, A.L.P.; d'Azevedo, P.A. (2007) Evaluation of oxacillin and cefoxitin disks for detection of resistance in coagulase negative staphylococci. Memórias do Intituto Oswaldo Cruz. Vol 102, pp. 719-23 ISSN 0074-0276

Caierão, J.; Musskopf, M., Superti, S., Roesch, E., Dias, C.G., d'Azevedo, P.A. (2004) Evaluation of phenotypic methods for methicillin resistance characterization in coagulase-negative staphylococci (CNS). Journal of Medical Microbiology. Vol. 53, pp.1195-1199, ISSN 0022-2615

Campanile, F.; Bongiorno, D.; Borbone, S.; Stefani, S. (2009) Hospital-associated methicillinresistant Staphylococcus aureus (HA-MRSA) in Italy. Annals of Clinical Microbiology and Antimicrobials. Vol. 24, pp. 8-22. ISSN 1476-0711 
CDC. Centers for Disease Control and Prevention. (2002) Staphylococcus aureus resistant to vancomycin-United States. Morbity and Mortality Weekly Reports.Vol. 51, pp. 565567. ISSN 0892-3787

CDC. Centers for Disease Control and Prevention. (2004) Brief Report: VancomycinResistant Staphylococcus aureus- New York. Morbity and Mortality Weekly Reports. Vol. 53, pp. 322-323. ISSN 0892-3787

CDC. Centers for Disease Control and Prevention. CDC Reminds Clinical Laboratories and Healthcare Infection Preventionists of their Role in the Search and Containment of Vancomycin-Resistant Staphylococcus aureus (VRSA), May 2010. Available at:

http://www.cdc.gov/HAI/settings/lab/vrsa_lab_search_containment.html. Accessed June 18, 2011.

Chaudhury, A.; Kumar, A.G. (2007) In vitro activity of antimicrobial agents against oxacillin resistant staphylococci with special reference to Staphylococcus haemolyticus. Indian Journal of Medical Microbiology.Vol.25, No.1, pp.50-52. ISSN 0255-0857

Cuevas, O.; Cercenado, E.; Goyanes, M.J.; Vindel, A.; Trincado, P.; Boquete, T.; Marín, M.; Bouza, E. (2008) Staphylococcus spp. in Spain: present situation and evolution of antimicrobial resistance (1986-2006). Enfermidades Infecciosas y Microbiología Clínica. Vol.26, pp.269-77. ISSN 1578-1852

Cookson, B.D.; Robinson, D.A.; Monk, A.B.; Murchan, S.; Deplano, A.; de Ryck, R.; Struelens, M.J.; Scheel, C.; Fussing, V.; Salmenlinna, S.; Vuopio-Varkila, J.; Cuny, C.; Witte, W.; Tassios, P.T.; Legakis, N.J.; van Leeuwen, W.; van Belkum, A.; Vindel, A.; Garaizar, J.; Haeggman, S.; Olsson-Liljequist, B.; Ransjo, U.; Muller-Premru, M.; Hryniewicz, W.; Rossney, A.; O'Connell, B.; Short, B.D.; Thomas, J.; O'Hanlon, S.; Enright, M.C. (2007) Evaluation of molecular typing methods in characterizing a European collection of epidemic methicillin-resistant Staphylococcus aureus strains: the HARMONY collection. Journal of Clinical Microbiology. Vol. 45, pp.1830-1837. ISSN 1098$660 \mathrm{X}$

De Lencastre, H.; Severina, E.P.; Milch, H.; Thege, M.K.; Tomasz, A. (1997) Wide geographic distribution of a unique methicillin-resistant Staphylococcus aureus clone in Hungarian hospitals. Clinical Microbiology and Infection. Vol. 3, pp. 289-296. ISSN:1198-743X

Ercis, S.; Sancak, B.; Hasçelik, G. (2008) A comparison of PCR detection of mecA with oxacillin disk susceptibility testing in different media and sceptor automated system for both Staphylococcus aureus and coagulase-negative staphylococci isolates. Indian Journal of Medical Microbiology. Vol. 26, pp. 21-4. ISSN 02550857

Gales, A.C.; Sader, H.S.; Ribeiro, J.; Zoccoli, C.; Barth, A.; Pignatari, A.C. (2009) Antimicrobial susceptibility of gram-positive bacteria isolated in Brazilian hospitals participating in the SENTRY Program (2005-2008). Brazilian Journal Infectious Diseases. 2009; 13: 90-8. ISSN 1413-8670 
Geng, W.; Yang, Y.; Wang, C.; Deng, L.; Zheng, Y.; Shen, X. (2010) Skin and soft tissue infections caused by community-associated methicillin-resistant Staphylococcus aureus among children in China. Acta Paediatrica. Vol. 99, pp. 575-580. ISSN 1651-2227

Herschleb, J.; Ananiev, G.; Schwartz, D.C. (2007) Pulsed-field gel electrophoresis. Nature Protocols. Vol. 2, pp.677-84. ISSN: 1754-2189

Higuchi, W.; Takano, T.; Teng, L.J.; Yamamoto, T. (2008) Structure and specific detection of staphylococcal cassette chromosome mec type VII. Biochemical and Biophysical Research Communications. Vol. 377, pp.752-756. ISSN: 0006-291X

Hiramatsu, K.; Hanaki, H.; Ino, T.; Yabuta, K.; Oguri, T.; Tenover, F.C. (1997) Methicillinresistant Staphylococcus aureus clinical strain with reduced vancomycin susceptibility. Journal of Antimicrobial Chemotherapy. Vol. 40, pp.135-136. ISSN 14602091

Hiramatsu, K.; Chui, L.; Kuroda, M.; Ito, T. (2001) The emergence and evolution of methicilin resistant Staphylococcus aureus. Trends Microbiology Vol. 9, pp. 486-93. ISSN: 0966-842X

Ho, P.L.; Wang, T.K.; Ching, P.; Mak, G.C.; Lai, E.; Yam, W.C.; Seto, W.H. (2007) Epidemiology and genetic diversity of methicillin-resistant Staphylococcus aureus strains in residential care homes for elderly persons in Hong Kong. Infection Control and Hospital Epidemiology. Vol. 28, pp. 671-678. ISSN:0899$823 \mathrm{X}$

International Working Group on the Classification of Staphylococcal Cassette Chromosome Elements (IWG-SCC). Classification of Staphylococcal Cassette Chromosome mec (SCCmec): Guidelines for Reporting Novel SCCmec Elements. Antimicrobial Agents Chemotherapy. Vol. 53, pp. 4961-4967. ISSN 0066-4804

International Working Group on the Staphylococcal Cassette Chromosome elements (IWGSCC). [Accessed on June 20, 2011]. SCCmec up to date. Available at: http://www.sccmec.org/Pages/SCC_TypesEN.html

Ito, T.; Okuma, K.; Ma, X.X.; Yuzawa, H.; Hiramatsu, K. (2003) Insights on antibiotic resistance of Staphylococcus aureus from its whole genome: genomic island SCC. Drug Resistance Update, Vol. 6, pp. 41-52. ISSN 1368-7646

Ito, T.; Ma, X.X.; Takeuchi, F.; Okuma, K.; Yuzawa, H.; Hiramatsu, K. (2004) Novel type V staphylococcal cassette chromosome mec driven by a novel cassette chromosome recombinase, ccrC. Antimicrobial Agents and Chemotherapy. Vol. 48, pp. 2637-2651. ISSN 0066-4804

Jain, A.; Agarwal, A.; Verma, R.K. (2008) Cefoxitin disc diffusion test for detection of meticillin-resistant staphylococci. Journal of Medical Microbiology. Vol. 57, p. 957-961. ISSN 0022-2615

Kloos, W.E.; Bannerman, T.L. (1995). Staphylococcus and Micrococcus, In: Manual of Clinical Microbiology, Murray, P.R., Baron, E.J., Pfaller, M.A., Tenover, F.C., Yolken, R.H., (Ed.), 282-298, ASM press, ISBN 13: 978-1555811266, Washington DC.

Köck, R.; Harlizius, J.; Bressan, N.; Laerberg, R.; Wieler, L.H.; Witte, W.; Deurenberg, R.H.; Voss, A.; Becker, K.; Friedrich, A.W. (2009) Prevalence and molecular characteristics of methicillin-resistant Staphylococcus aureus (MRSA) among pigs on German farms and import of livestock-related MRSA into hospitals. European 
Journal of Clinical Microbiology E Infectious Diseases. Vol. 28, pp. 1375-1382. ISSN 0934-9723

Ma, X.X.; Ito, T.; Tiensasitorn, C.; Jamklang, M.; Chongtrakool, P.; Boyle-Vavra, S.; Daum, R.S.; Hiramatsu, K. (2002) Novel type of staphylococcal cassette chromosome mec identified in community-acquired methicillin-resistant Staphylococcus aureus strains. Antimicrobial Agents and Chemotherapy. Vol. 46, pp. 1147-52. ISSN 0066-4804

Maiden, M.C.; Bygraves, J.A.; Feil, E.; Morelli, G.; Russell, J.E.; Urwin, R.; Zhang, Q.; Zhou, J.; Zurth, K.; Caugant, D.A.; Feavers, I.M.; Achtman, M.; Spratt, B.G. (1998) Multilocus sequence typing: a portable approach to the identification of clones within populations of pathogenic microorganisms. Proceedings of the National Academy of Sciences, USA. Vol. 95, pp. 3140-3145. ISSN: 00278424.

Malachowa, N.; Sabat, A.; Gniadkowski, M.; Krzyszton-Russjan, J.; Empel, J.; Miedzobrodzki, J.; Kosowska-Shick, K.; Appelbaum, P.C.; Hryniewicz, W. (2005) Comparison of multiple-locus variable-number tandem-repeat analysis with pulsed-field gel electrophoresis, spa typing, and multilocus sequence typing for clonal characterization of Staphylococcus aureus isolates. Journal of Clinical Microbiology. Vol. 43, pp. 3095-100. ISSN 1098-660X.

Martins, A.; Pereira, V.C.; Cunha, M.L.R.S. (2010) Oxacillin resistance of Staphylococcus aureus isolated from the university hospital of Botucatu Medical School in Brazil. Chemotherapy. Vol. 56, pp. 112-9. ISSN 0009-3157.

McDougal, L.K.; Thornsberry, C. (1986) The role of beta-lactamase in staphylococcal resistance to penicillinase-resistant penicillins and cephalosporins. Journal of Clinical Microbiology. Vol. 23, pp. 832-839. ISSN 1098-660X.

Melter, O.; Aires De Sousa, M.; Urbaskova, P.; Jakubu, V.; Zemlickova, H.; De Lencastre, H. (2003) Update on the major clonal types of methicillin-resistant Staphylococcus aureus in the Czech Republic. Journal of Clinical Microbiology. Vol. 41, pp.4998-4905. ISSN 1098-660X.

Miragaia, M.; Thomas, J.C.; Couto, I.; Enright, M.C.; de Lencastre, H. (2007) Inferring a population structure for Staphylococcus epidermidis from multilocus sequence typing data. The Journal of Bacteriology. Vol. 189, pp. :2540-2552. ISSN 10985530

Molina, A.; Del Campo, R.; Máiz, L.; Morosini, M.I.; Lamas, A.; Baquero, F.; Cantón, R. (2008) High prevalence in cystic fibrosis patients of multiresistant hospital-acquired methicillin-resistant Staphylococcus aureus ST228-SCCmecI capable of biofilm formation. Journal of Antimicrobial Chemotherapy. Vol 62, pp. 961-967. ISSN 14602091

Mombach Pinheiro Machado A.B.; Reiter, K.C.; Paiva, R.M.; Barth, A.L. (2007) Distribution of staphylococcal cassette chromosome mec (SCCmec) types I, II, III and IV in coagulase-negative staphylococci from patients attending a tertiary hospital in southern Brazil. Journal of Medical Microbiology. Vol. 56, pp.1328-1333. ISSN 00222615 
Neela, V.; Ghasemzadeh Moghaddam, H.; van Belkum, A.; Horst-Kreft, D.; Mariana, N.S.; Ghaznavi Rad, E. (2010) First report on methicillin-resistant Staphylococcus aureus of Spa type T037, Sequence type 239, SCCmec type III/IIIA in Malaysia. European Journal of Clinical Microbiology \& Infectious Diseases. Vol. 29, pp. 115-117. ISSN 09349723

O'Brien, F.G.; Zaini, Z.; Coombs, G.W.; Pearson, J.C.; Christiansen, K.; Grubb, W.B.; Macrolide, lincosamide and streptogramin B resistance in a dominant clone of Australian community methicillin-resistant Staphylococcus aureus. Journal of Antimicrobial Chemotherapy, Vol. 56; pp. 985-986. ISSN 1460-2091.

Oliveira, G.A.; Faria, J.B.; Levy, C.E.; Mamizuka, E.M. (2001) Characterization of the Brazilian endemic clone of methicillin-resistant Staphylococcus aureus (MRSA) from hospitals throughout Brazil. Brazilian Journal of Infectious Diseases.Vol. 5, pp. 163170. ISSN 1413-8670

Oliveira, D.C.; Tomasz, A.; De Lencastre, H. (2002) Secretes of sucess of a human pathogen: molecular evolution of pandemic clones of methicilin-resistant Staphylococcus aureus. The Lancet Infectious Disease. Vol. 2, pp. 180-189. ISSN 14733099

Oliveira, D.C.; Milheiriço, C.; de Lencastre, H. (2006) Redefining a structural variant of staphylococcal cassette chromosome mec, SCCmec type VI. Antimicrobial Agents and Chemotherapy. Vol. 50, pp. 3457-3459. ISSN 0066-4804

Peacock, S.J., de Silva, G.D.; Justice, A.; Cowland, A.; Moore, C.E.; Winearls, C.G.; Day, N.P. (2002) Comparison of multilocus sequence typing and pulsed-field gel electrophoresis as tools for typing Staphylococcus aureus isolates in a microepidemiological setting. Journal of Clinical Microbiology. Vol. 40, pp. 3764-70. ISSN 1098-660X

Pereira, V.C.; Martins, A.; Rugolo, L.M.S.S.; Cunha, M.L.R.S. (2009)Detection of Oxacillin Resistance in Staphylococcus aureus Isolated from the Neonatal and Pediatric Units of a Brazilian Teaching Hospital. Clinical Medicine: Pediatrics. Vol. 3, pp. 23-31. ISSN: 1179-5565

Perez, L.R.R.; d'Azevedo, P.A. (2008) Evaluation of the Accuracy of Various Phenotypic Tests to Detect Oxacillin Resistance in Coagulase-Negative Staphylococci. Brazilian Journal Infectious Diseases. Vol. 12, pp.210-212. ISSN 1413-8670

Sader, H.S.; Jones, R.N.; Gales, A.C.; Silva, J.B.; Pignatari, A.C. (2004) SENTRY antimicrobial surveillance program report: Latin American and Brazilian results for 1997 through 2001. Brazilian Journal of Infectious Diseases. Vol. 8, pp.25-79. ISSN 14138670

Sader, H.S.; Watters, A.A.; Fritsche, T.R.; Jones, R.N. (2007) Daptomycin antimicrobial activity tested against methicillin-resistant staphylococci and vancomycin-resistant enterococci isolated in European medical centers (2005). BMC Infectious Disease. Vol. 18, pp.7-29. ISSN 1471-2334

Sader, H.S.; Jones, R.N. (2009) Antimicrobial susceptibility of Gram-positive bacteria isolated from US medical centers: results of the Daptomycin Surveillance Program (2007-2008). Diagnostic Microbiology and Infectious Disease. 2009, Vol. 65, pp.158-162. ISSN: 07328893. 
Secchi, C.; Antunes, A.L.; Perez, L.R.; Cantarelli, V.V.; d'Azevedo, P.A. (2008) Identification and detection of methicillin resistance in non-epidermidis coagulase-negative staphylococci. Brazilian Journal of Infectious Diseases. Vol. 12, pp. 316-320. ISSN 14138670

Shore, A.; Rossney, A.S.; Keane, C.T.; Enright, M.C.; Coleman, D.C. (2005) Seven novel variants of the staphylococcal chromosomal cassette mec in methicillin-resistant Staphylococcus aureus isolates from Ireland. Antimicrobial Agents and Chemotherapy 2005; Vol. 49, pp. 2070-2083. ISSN 0066-4804

Smith, T.C.; Male, M.J.; Harper, A.L.; Kroeger, J.S.; Tinkler, G.P.; Moritz, E.D.; Capuano, A.W.; Herwaldt, L.A; Diekema, D.J. (2009) Methicillin-resistant Staphylococcus aureus (MRSA) strain ST398 is present in midwestern U.S. swine and swine workers. PLoS One. Vol. 4, pp. e4258. ISSN 1932-6203Sola, C.; Cortes, P.; Saka, H.A.; Vindel, A.; Bocco, J.L. (2006) Evolution and molecular characterization of methicillin-resistant Staphylococcus aureus epidemic and sporadic clones in Cordoba, Argentina. Journal of Clinical Microbiology. Vol. 44, pp.192-200. ISSN 1098$660 X$

Swenson, J.M. (2002) New tests for the detection of oxacillin-resistant Staphylococcus aureus. Clinical Microbiology Newsletter, Vol. 24, pp. 159-163. ISSN: 0196-4399

Teixeira, L.A.; Resende, C.A.; Ormonde, L.R.; Rosenbaum, R.; Figueiredo, A.M.; De Lencastre, H.; Tomasz, A. (1995) Geographic spread of epidemic multiresistant Staphylococcus aureus clone in Brazil. Jounal of Clinical Microbiology. Vol. 33, pp. 24002404. ISSN 1098-660X

Tomasz, A.; Drugeon, H.B., de Lencastre, H.M.; Jabes, D.; McDougall, L.; Bille, J. (1989) New mechanism for methicillin resistance in Staphylococcus aureus: clinical isolates that lack the PBP 2a gene and contain normal penicillin-binding proteins with modified penicillin-binding capacity. Antimicrobial Agents and Chemotherapy. Vol. 33, pp. 1869-1874. ISSN 0066-4804

Tomasz, A.; Nachman, S.; Leaf, H. (1991) Stable classes of phenotypic expression in methicillin-resistant clinical isolates of staphylococci. Antimicrobial Agents and Chemotherapy. Vol. 35, pp. 124-129. ISSN 0066-4804.

Velazquez-Meza, M.E.; Aires De Sousa, M.; Echaniz-Aviles, G.; Solorzano-Santos, F.; Miranda-Novales, G.; Silva-Sanchez, J.; De Lencastre, H. (2004) Surveillance of methicillin-resistant Staphylococcus aureus in a pediatric hospital in Mexico City during a 7-year period (1997 to 2003): clonal evolution and impact of infection control. Journal of Clinical Microbiology, Vol. 42, pp. 3877-80. ISSN 1098$660 \mathrm{X}$

Vindel, A.; Cuevas, O.; Cercenado, E.; Marcos, C.; Bautista, V.; Castellares, C.; Trincado, P.; Boquete, T.; Pérez-Vázquez. M.; Marín, M.; Bouza, E. (2009) Methicillin-resistant Staphylococcus aureus in Spain: molecular epidemiology and utility of different typing methods. Journal of Clinical Microbiology. Vol. 47, pp. 1620-1627. ISSN 1098$660 X$

Vuong, C.; Otto, M. (1999) Staphylococcus epidermidis infections. Microbes and Infection. Vol. 4, pp. 481-489. ISSN:1286-4579

Witte, W. (1999) Antibiotic resistance in gram-positive bacteria: epidemiological aspects. Journal of Antimicrobial Chemotherapy. Suppl A:1-9. ISSN 1460-2091 
Zhang, K.; McClure, J.A.; Elsayed, S.; Conly, J.M. (2009) Novel staphylococcal cassette chromosome mec type, tentatively designated type VIII, harboring class A mec and type $4 \mathrm{ccr}$ gene complexes in a Canadian epidemic strain of methicillin-resistant Staphylococcus aureus. Antimicrobial Agents and Chemotherapy. Vol. 53, pp. 531-540. ISSN 0066-4804 


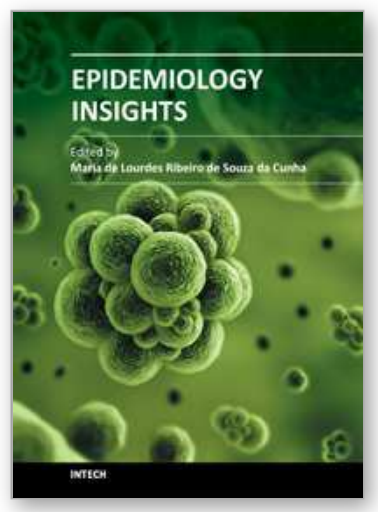

\author{
Epidemiology Insights \\ Edited by Dr. Maria De Lourdes Ribeiro De Souza Da Cunha
}

ISBN 978-953-51-0565-7

Hard cover, 396 pages

Publisher InTech

Published online 20, April, 2012

Published in print edition April, 2012

This book represents an overview on the diverse threads of epidemiological research, brings together the expertise and enthusiasm of an international panel of leading researchers to provide a state-of-the art overview of the field. Topics include the epidemiology of dermatomycoses and Candida spp. infections, the epidemiology molecular of methicillin-resistant Staphylococcus aureus (MRSA) isolated from humans and animals, the epidemiology of varied manifestations neuro-psychiatric, virology and epidemiology, epidemiology of wildlife tuberculosis, epidemiologic approaches to the study of microbial quality of milk and milk products, Cox proportional hazards model, epidemiology of lymphoid malignancy, epidemiology of primary immunodeficiency diseases and genetic epidemiology family-based. Written by experts from around the globe, this book is reading for clinicians, researchers and students, who intend to address these issues.

\title{
How to reference
}

In order to correctly reference this scholarly work, feel free to copy and paste the following:

André Martins and Maria de Lourdes Ribeiro de Souza da Cunha (2012). Epidemiological Aspects of OxacillinResistant Staphylococcus spp.: The Use of Molecular Tools with Emphasis on MLST, Epidemiology Insights, Dr. Maria De Lourdes Ribeiro De Souza Da Cunha (Ed.), ISBN: 978-953-51-0565-7, InTech, Available from: http://www.intechopen.com/books/epidemiology-insights/epidemiological-aspects-of-oxacillin-resistantstaphylococcus-spp-the-use-of-molecular-tools-with

\section{INTECH}

open science | open minds

\section{InTech Europe}

University Campus STeP Ri

Slavka Krautzeka 83/A

51000 Rijeka, Croatia

Phone: +385 (51) 770447

Fax: +385 (51) 686166

www.intechopen.com

\section{InTech China}

Unit 405, Office Block, Hotel Equatorial Shanghai

No.65, Yan An Road (West), Shanghai, 200040, China

中国上海市延安西路65号上海国际贵都大饭店办公楼 405 单元

Phone: +86-21-62489820

Fax: $+86-21-62489821$ 
(C) 2012 The Author(s). Licensee IntechOpen. This is an open access article distributed under the terms of the Creative Commons Attribution 3.0 License, which permits unrestricted use, distribution, and reproduction in any medium, provided the original work is properly cited. 